\title{
COMMENTS
}

\section{PERMISSIBLE SCOPE OF CEASE AND DESIST ORDERS: LEGISLATION AND ADJUDICATION BY THE FTC}

The congressional grant of power to the Federal Trade Commission to detect and prohibit unfair trade practices represents a significant limitation on a free enterprise economy. The sole means by which this power is exercised is through the issuance of cease and desist orders. Despite the important role which these orders play in regulating the American business community, -no workable theory has yet been advanced to govern the determination of their permissible breadth.

This comment has two purposes. The first is to trace the development of the "law" governing the permissible scope of FTC orders. Since recent cases in the Supreme Court and the Court of Appeals for the Second Circuit suggest that this development has reached a 'critical stage, ${ }^{1}$ such a survey is of particular current interest. The second objective is to analyze the problems of breadth of cease and desist orders from the standpoint of the legislative and judicial function which they perform. While the approach is novel in this context, it is believed that the scheme will prove helpful in understanding the nature and effect of cease and desist orders and the factors which should be considered in determining their proper scope.

It should be noted that although the central inquiry concerns the proper breath of FTC orders, similar problems appear whenever an administrative agency is empowered to enforce the law by means of cease and desist orders. Accordingly, orders issued by the National Labor Relations Board in unfair labor practice cases will be used for comparative purposes.2

\section{I.}

The FTC is authorized to issue and serve a complaint stating charges and giving notice of a hearing upon any person ${ }^{3}$ the Commission has reason to believe is violating the Federal Trade Commission Act, ${ }^{4}$ the Robinson-Pat-

1 FTC. v. Henry Broch \& Co., 368 U.S. 360 (1962); American News Co. v. FTC, 300 F.2d 104 (2d Cir. 1962); Grand Union Co. v. FTC, 300 F.2d 92 (2d Cir. 1962); Swanee Paper Corp. v. FTC, 291 F.2d 833 (2d Cir. 1961).

2 The reason for selecting the NLRB for comparative purposes is that of the agencies authorized to issue cease and desist orders, the two which have made most frequent use of the device are the FTC and the NLRB.

3 Hereinafter referred to as respondent.

438 Stat. 717 (1914), 15 U.S.C. $§ \$ 41-58$ (1958). 
man Act, 5 the Clayton Act, 6 or one of the Labeling Acts. 7 If upon such hearing the Commission is of the opinion that the respondent is in fact in violation, it may issue a cease and desist order. ${ }^{8}$ Judicial review may be obtained by the respondent in the court of appeals for the circuit where the act in question occurred or where the respondent resides or does business.9

The cease and desist order functions more as a prohibition than as a punishment in that it imposes no immediate penalty for the violations found.10 Sanctions may be imposed only if the respondent commits the acts prohibited by the order subsequent to its issuance. In contrast to orders issued by some agencies"1 FTC orders may be enforced without judicial action. If no petition for review is filed within sixty days from the date of the service of the order, it becomes "final,"12 and the prohibited conduct is punishable by a fine of $\$ 5,000$ for each day of continuing violation. 13

Problems of the permissible breadth of cease and desist orders exemplify what Professor Davis has termed a fundamental problem of administrative law: the need to reconcile the conflicting goals of effective administration and fair procedure. $14 \mathrm{On}$ one hand, if the original order is too narrow, the administrative agency, faced with the responsibility of supervising large and com-

538 Stat. 730 (1914), as amended, 49 Stat. 1526 (1936), 15 U.S.C. $\$ 13$ (1958).

638 Stat. 730 (1914), 15 U.S.C. \$ 13 (1958).

7 Wool Products Labeling Act, 54 Stat. 1133 (1940), 15 U.S.C. $\$ 68$ (1958); Fur Products Labeling Act, 65 Stat. 181 (1951), 15 U.S.C. $\$ 69$ (1958); Textile Fiber Products Identification Act, 72 Stat. 1724, (1958), 15 U.S.C. $\$ 70$ (1958).

838 Stat. 722 (1914), 15 U.S.C. $\$ 45(b)$ (1958).

9 Ibid.

${ }^{10}$ Although the cease and desist order mechanism is controlled by statute, the device is similar in its effect to an injunction issued by a court of equity. See Freer, Federal Trade Commission Procedure and Practice, 8 GEO. WASH. L. Rev. 316, 330 (1940). The problem of the proper breadth of an injunctive decree is therefore older than the Federal Trade Commission. See Swift \& Co. v. United States, 196 U.S. 375, 396 (1905); Laurie v. Laurie, 9 Paige 233, 235 (N.Y. 1841).

${ }^{11}$ An NLRB order, for example, imposes no effective legal sanctions until supplemented by a judicial enforcing order, which may be issued by any court of appeals of the United States on petition by the Board, 49 Stat. 449 (1936), 15 U.S.C. $\$ 160($ e) (1958).

1238 Stat. 722 (1914), 15 U.S.C. $\$ 45(g)$ (1958).

13 The procedure described above has been used by the Commission in enforcing its orders under the Federal Trade Commission Act since 1938, and under the Robinson-Patman Act since 1959. Prior to 1959 Robinson-Patman orders could not be enforced unless supplemented by a court order. The procedure was similar to that which is employed by the NLRB; it differed in that the Commission could not petition for review unless the violations continued. This allowed three violations before effective sanctions could be imposed. See Countryman, The Federal Trade Commission and the Courts, 16 Wash. L. Rev. 1 (1942). The possible effect of the two procedures on the permissible scope of orders will be discussed at notes 89 and 90 , infra.

${ }^{14}$ Davis, Ombudsmen in America: Officers to Criticize Administrative Action, 109 U. PA. L. REv. 1057, 1062 (1961). 
plex areas of activity, may be required to bear the additional expense and inconvenience of issuing further orders to cover only slightly varied subsequent violations. Cease and desist order procedure is slow and expensive; if, subsequent to the issuance of the order, the respondent engages in conduct forbidden by the statute but not by his order, the agency must either ignore these violations or institute new proceedings. 15 Thus, the temptation to issue blanket orders prohibiting all varieties of future misconduct is strong. On the other hand, Congress has manifested its intention that certain statutes be enforced through the cease and desist order mechanism rather than by immediate punishment; an excessively broad order in effect defeats that intention by depriving the respondent of the one unpunishable violation which the statute allows. A broad order operates much like a criminal statute applicable only to the respondent. Others may engage in the activities which respondent's order prohibits without fear of more severe action than the imposition of a similar order as to them, but a violation by the respondent is immediately punishable. 16

The traditional "test" for determining the permissible scope of administrative orders is that the court must find a "reasonable relation" between the violations proved and the activities prohibited. Although the reasonable relation test is applied to orders issued by both the FTC17 and the NLRB, 18 it is submitted that the majority of the courts are in fact applying the test much more strictly to orders of the Labor Board than to those of the Trade Commission. This difference in the treatment of the orders of the two agencies affords an appropriate point at which to begin the present discussion.

A necessary determinant of the permissible breadth of an order is the extent to which the reviewing court is free to substitute its judgment for that of the agency: Greater judicial deference toward the agency results in greater reluctance to narrow the scope of the remedy selected. Since the amendment of the National Labor Relations Act in 1947,19 the courts have given effect to a congressional intent that Labor Board orders should be scrutinized more intensively than had been the approach prior to the amendment.20 Prior to

15 A third alternative, which the Commission often employs with great effectiveness is the application of informal pressure, leading to informal adjudication. See 1 DAVIS, ADMINISTRATIVE LAW $\$ 4.02$ (1958).

16 The possible inequities accruing to the recipient of a broad order will be developed more fully infra, pp. 721-23.

17 See Jacob Siegel Co. v. FTC, 327 U.S. 608, 613 (1946); Gellman v. FTC, 290 F.2d 666, 670 (8th Cir. 1961).

18 See NLRB v. Express Publishing Co., 312 U.S. 426, 436 (1941); NLRB v. Firedoor Corp. of America, 291 F.2d 328, 332 (2d Cir. 1961).

1961 Stat. 104 (1947), 29 U.S.C. § 141 (1958).

20 Compare, e.g., NLRB v. Capitol Greyhound Lines, 140 F.2d 754 (6th Cir. 1944); NLRB v. Standard Oil Co., 138 F.2d 885 (2d Cir. 1943); Jacobsen v. NLRB, 120 F.2d 96 (3d Cir. 1941); NLRB v. Union Pac. Stages, Inc., 99 F.2d 153 (9th Cir. 1938), with 
1947 the approach generally prevalent in the courts of appeals was that "the course to be pursued rests in the sound discretion of the Board and is the concern of expert administrative policy."21 However, the courts now seem to place upon the Board the burden of justifying the need for an order broader than the particular violations found.22 Though an occasional opinion still refers to the "broad discretion" of the Board in framing its orders, this discretion is no longer controlling. 23 The procedure of the reviewing court is to compare the prohibitions of the order with the proven violations; if the two coincide there is no problem of excessive breadth, and the order will be enforced as drafted. But if the order prohibits activities other than the respondent's proven misconduct, the court must determine whether the Board's findings reasonably support the inference that the respondent intends to engage in the acts prohibited by the order. If the court finds no such reasonable inference it will narrow the order to the violations found. ${ }^{24}$ Subjective intention to commit other unfair labor practices need not be shown; it may be inferred from such findings as frequent past violations ${ }^{25}$ or lack of good faith. ${ }^{26}$

NLRB v. Enterprise Ass'n, 285 F.2d 642 (2d Cir. 1960); NLRB v. Local 751, United Bhd. of Carpenters, 284 F.2d 633 (9th Cir. 1960); NLRB v. Brandman Iron Co., 281 F.2d 797 (6th Cir. 1960) (per curiam); NLRB v. United Bhd. of Carpenters, 276 F.2d 694 (7th Cir. 1960); NLRB v. Richards, 265 F.2d 855 (3d Cir. 1959).

21 Jacobsen v. NLRB, 120 F.2d 96, 100 (3d Cir. 1941).

22 In Int'l Bhd. of Teamsters v. NLRB, 262 F.2d 456, 462 (D.C. Cir. 1958), the court said: "True, the Board did find that the evidence warranted a cease and desist order which is broader than usual; nevertheless, in cases involving such broad orders the Board not only must make a finding, based upon substantial evidence on the record as a whole, that the blanket order is required, but it must also convince the court that such an order is needed." (Emphasis added.)

23 NLRB v. Local 926, Int'l Union of Operating Eng'r, 267 F.2d 418, 420 (5th Cir. 1959). The 1947 amendment did not take away all discretionary power from the NLRB. For example, under section $9(\mathrm{~b})$ of the Labor Management Relations Act, the determination of the appropriate bargaining unit is left to the discretion of the Board. Judicial review of orders which involve a Board decision on this matter is narrowly limited. See NLRB v. Packard Motor Car Co., 330 U.S. 485 (1947); Pittsburgh Plate Glass Co. v. NLRB, 313 U.S. 146 (1941); Texas Pipe Line Co. v. NLRB, 296 F.2d 208 (5th Cir. 1961).

24 See, e.g., NLRB v. Int'l Hod Carriers, 285 F.2d 397 (8th Cir. 1960); NLRB v. Brewery \& Beer Distributor Drivers, 281 F.2d 319 (3d Cir. 1960); NLRB v. Int'l Ass'n of Machinists, 279 F.2d 761 (9th Cir. 1960); NLRB v. Bangor Bldg. Trades Council, 278 F.2d 287 (1st Cir. 1960); Morrison-Knudsen, Inc. v. NLRB, 270 F.2d 864 (9th Cir. 1959); NLRB v. Local 926, Int'l Union of Operating Eng'r, 267 F.2d 418 (5th Cir. 1959); Truck Drivers \& Helpers v. INLRB, 265 F.2d 439 (5th Cir. 1959); NLRB v. Lamar Creamery Co., 246 F.2d 8 (5th Cir. 1957); Lion Oil Co. v. NLRB, 245 F.2d 376 (8th Cir. 1957).

If the court affirms the order as drafted, it does so not because it relies on the discretion of the Board, but because in the court's judgment the order is a proper one. See, e.g., NLRB v. Local 135, Int'l Bhd. of Teamsters, 267 F.2d 870 (7th Cir. 1959); NLRB v. Springfield Bldg. \& Const. Trades Council, 262 F.2d 494 (1st Cir. 1958); NLRB v. Newspaper \& Mail-Deliverers Union, 246 F.2d 62 (3d Cir. 1957).

25 NLRB v. Cheney California Lumber Co., 327 U.S. 385 (1946); NLRB v. Int'l Hod Carriers, 285 F.2d 397 (8th Cir. 1960); NLRB v. Brewery \& Beer Distrib. Drivers, 281 F.2d 319 
In contrast, the approach most frequently taken by courts in reviewing FTC orders is to allow the Federal Trade Commission "wide discretion" in framing its orders, a discretion that is controlling unless clearly abused.27 As a result of this reluctance to upset the remedy chosen by the Commission, ${ }^{28}$ judicial

(3d Cir. 1960); NLRB v. Local 135, Int'1 Bhd. of Teamsters, 267 F.2d 870 (7th Cir. 1959); NLRB v. Newspaper \& Mail Deliverers Union, 246 F.2d 62 (3d Cir. 1957). No court has explicitly stated that the significance of the frequency of respondent's past violations derives from the fact that such violations are indicative of probable intention. This is very strongly implied, however, by such Supreme Court opinions as McComb v. Jacksonville Paper Co., 336 U.S. 187, 192 (1949), in which the opinion-referred to the "continuing and persistent violations" as manifesting a "proclivity for unlawful conduct," and Communications Workers of America v. NLRB, 362 U.S. 479, 480 (1960) (per curiam), in which the Court modified the order as too broad because the acts of the union did not evidence a "generalized scheme."

26 NLRB v. Crompton-Highland Mills, Inc., 337 U.S. 217, 226 (1949).

27 Jacob Siegel Co. v. FTC, 327 U.S. 608, 611 (1940). For recent cases applying this principle, see Exposition Press, Iric. v. FTC, 295 F.2d 869 (2d Cir. 1961); Holland Furnace Co. v. FTC, 295 F.2d 302 (7th Cir. 1961); Bigelow-Sanford Carpet Co. v. FTC, 294 F.2d 718 (D.C. Cir. 1961); Samuel A. Mannis Co. v. FTC, 293 F.2d 774 (9th Cir. 1961); Hoving Corp. v. FTC, 290 F.2d 803 (2d Cir. 1961); Gellman v. FTC, 290 F.2d 666 (8th Cir. 1961); Huntèr Mills Corp. v. FTC, 284 F.2d 70 (2d Cir. 1960); Niresk Indus. v. FTC, 278 F.2d 337 (7th Cir. 1960); Erickson v. FTC, 272 F.2d 318 (7th Cir. 1959); Arrow Metal Products Corp. v. FTC, 249 F.2d 83 (3d Cir. 1957); Chain Institute v. FTC, 246 F.2d 231 (8th Cir. 1957).

28 In Universal Camera Corp. v. NLRB, 340 U.S. 474 (1951), Mr. Justice Frankfurter stated that in the 1947 amendment to the National Labor Relations Act Congress expressed a "mood" that decisions of all administrative agencies were to be subjected to more penetrating scrutiny by the reviewing court. Consequently, he asserted, the scope of review applicable to all agencies under the Administrative Procedure Act would be the same as that of the NLRB under the Taft-Hartley Act. Whether or not this change has in fact occurred in other contexts, an examination of the cases on this subject since 1957 reveals that in reviewing the scope of an FTC cease and desist order, only the Fourth Circuit has consistently refused to defer to the discretion of the Commission. See Asheville Tobacco Bd. of Trade, Inc. v. FTC, 294 F.2d 619 (4th Cir. 1961); Asheville Tobacco Bd. of Trade, Inc. v. FTC, 263 F.2d 502 (4th Cir. 1959); Virginia Excelsior Mills v. FTC, 256 F.2d 538 (4th Cir. 1958).

The Seventh Circuit has at times deferred to the discretion of the Commission, Holland Furnace Co. v. FTC, 295 F.2d 302 (7th Cir. 1961); Niresk Indus. v. FTC, 278 F.2d 337 (7th Cir. 1960); Erickson v. FTC, 272 F.2d 318 (7th Cir. 1959), and at times has not. Henry Broch \& Co. v. FTC, 285 F.2d 764 (7th Cir. 1960); Mandel Bros., Inc. v. FTC, 254 F.2d 18 (7th Cir. 1958). Both Broch and Mandel were reversed by the Supreme Court on the breadth issue. FTC v. Henry Broch \& Co., 368 U.S. 360 (1962); FTC v. Mandel Bros., Inc., 359 U.S. 385 (1959).

The Second Circuit in three recent cases, American News Co. v. FTC, 299 F.2d 104 (2d Cir. 1962); Grand Union Co. v. FTC, 299 F.2d 92 (2d Cir. 1962); and Swanee Paper Corp. v. FTC, 291 F.2d 833 (2d Cir. 1961), has mentioned the wide discretion of the Commission, but nevertheless narrowed the scope of the order to the particular violations found. These cases all involved orders issued under the new enforcement procedure of the Robinson-Patman Act. They may be pointing toward a new approach to these orders. See infra notes $104-14$ and accompanying text.

The cases in which the courts have deferred to FTC discretion and refused to narrow the scope of the order are cited at note 27, supra. The complete shift under the Taft-Hartley Act away from reliance on Labor Board discretion in determining the scope of NLRB orders has not been accompanied by a similar change under the Administrative Procedure Act as to the scope of FTC orders. The majority of the circuits will modify an FTC cease and desist order only if there has been an abuse of discretion. 
modification of an FTC order is comparatively rare. 29 Thus, proof of a single violation, unsupplemented by other findings indicative of the respondent's intention, will often support an order enjoining the commission of similar unfair practices "in any other manner." 30

The courts' treatment of the permissible scope of NLRB orders is relevant to this comment only insofar as the comparison highlights the problem of the proper scope of FTC orders. It is apparent that the reasonable relation test is being applied much more strictly to orders of the NLRB than to those of the FTC. In view of the different functions performed by the orders of these two agencies, it would seem that under proper circumstances ${ }^{31}$ this difference in treatment is not only good policy but is consistent with congressional intent. Unfortunately, however, the majority of the courts have deferred to the discretion of the Commission without reference to the function performed by the order.

The basis of this functional difference is found in the statutes administered by the FTC and the NLRB. The National Labor Relations Act authorizes the NLRB to issue cease and desist orders to enjoin the commission of unfair labor practices, but it does not allow the Board complete freedom to make its own determination as to the activities which constitute such practices. A Board order may prohibit only those acts which fall within the reach of one of the twelve classifications enumerated in sections $8(a)$ and $8(b) .32$ Thus, the cease and desist order procedure of the NLRB is analogous to that of a criminal court in determining whether given activities fall within the ambit of specified categories of conduct prohibited by the legislature.

In contrast, the Federal Trade Commission Act contains no congressionally defined categories of practices within which the agency's orders must be confined. The Act simply declares that "unfair methods of competition in commerce and unfair or deceptive acts or practices in commerce, are ... unlawful ${ }^{\prime \prime} 33$ and authorizes the Commission to prevent the use of such unfair methods by issuing cease and desist orders. The determination of the activ $\mathrm{i}$ -

29 Respondents counsel advocating that the scope of an FTC order be narrowed frequently rely for their precedents chiefly on cases involving NLRB orders. Sce, e.g., Brief for Respondent, FTC v. Henry Broch \& Co., 368 U.S. 360 (1962). Brief for Respondent, pp. 36-41 ; FTC v. Mandel Brothers, Inc., 359 U.S. 385 (1959).

${ }^{30}$ E.g., FTC v. Henry Broch \& Co., 368 U.S. 360 (1962); Niresk Indus., Inc. v. FTC, 278 F.2d 337 (7th Cir. 1960). infra.

31 What these circumstances are will be developed in the text accompany ing notes $72-74$,

32 For example, prior to the enactment of the Labor Management Reporting and Disclosure Act 73 Stat. 519 (1959), which added a new category of union unfair labor practices, $\S 8(b)(7)$, the NLRB could not issue an order to a minority non-certified union to cease and desist from "recognitional" picketing, regardless of how "unfair" the Board regarded this practice. See NLRB v. Drivers, Chauffeurs, Helpers Local Union 639, 362 U.S. 274 (1960).

3338 Stat. 722 (1914), 15 U.S.C. § 45(a)(1)(1958). 
ties or types of activities to be regarded as "unfair" is left to the Commission. ${ }^{34}$.

A similar situation exists under the Robinson-Patman Act, but for a different reason. The evil at which the Act is directed is price discrimination, and, like the National Labor Relations Act, the legislation specifies particular types of practices which may be prohibited as "discriminatory." Unlike the NLRA, however, the Robinson-Patman Act does not mark the outer limits of discriminatory pricing practices which the Commission may enjoin. A course of conduct which violates the spirit of the Robinson-Patman Act but does not fall within one of the statutory categories may nevertheless be prohibited by the Commission as an "unfair method of competition" under section 5 of the Federal Trade Commission Act. 35 This effectively extends the power of the Commission to probibit price discrimination beyond the categories of practices enunciated in the Robinson-Patman Act. Furthermore, the Act has been noted since the time of its enactment for its "vague and general wording." 36 From the language of a particular provision it is not possible to ascertain the types of conduct which the provision is intended to prohibit. ${ }^{37}$ This vagueness has been extensively treated elsewhere;38 its signifcance for present purposes is that the responsibility of giving specific content to the Act falls upon the FTC. ${ }^{39}$ Only as the Commission applies the language of the statute to particular practices does its meaning become clear.

${ }^{34}$ See S. Rep. No. 597, 63d Cong. 2d Sess. 13 (1914), in which the Senate Committee on Interstate Commerce explains its decision not to construct the Act upon the same scheme which was later used in drafting the NLRA: "The Committee gave careful consideration to the question as to whether it would attempt to define the many and variable unfair practices which prevail in commerce and to forbid their continuance or whether it would, by a general declaration condemning unfair practices, leave it to the commission to determine what practices. were unfair. It concluded that the latter course would be the better, for the reason ... that there were too many unfair practices to define, and after writing 20 of them into law it would be quite possible to invent others .... The committee was of the opinion that it would be better to put in a general provision condemning unfair competititon than to attempt to define the numerous unfair practices ...."

35 See Grand Union Co. v. FTC, 300 F.2d 92 (2d Cir. 1962); American News Co. v. FTC, 300 F.2d 104 (2d Cir. 1962), discussed in note 106, infra.

36 Ruberoid Co. v. FTC, 189 F.2d 893, 894-95 (2d Cir. 1951). In congressional debate on the bill Representative Emmanuel Celler (D. N.Y.) stated: "Bills oft times are vague and ambiguous. You might as well know that the bill agreed on by the conferees contains many inconsistencies, and the courts will have the devil's own job to unravel the tangle." 80 CoNG. ReC. 9419 (1936).

${ }^{37}$ See, e.g., FTC v. Henry Broch \& Co., 368 U.S. 360 (1962); Swanee Paper Corp. v. FTC, 291 F.2d 833 (2d Cir. 1961).

38 See Edwards, The Price Discrimination Law 28 (1959) Thereinafter cited as EDWARDsl and Rowe, The Evolution of the Robinson-Patman Act: $A$ Twenty-Year Perspective, 57 ColUm. L. REv. 1059 (1957). See also Mr. Justice Jackson's dissenting opinion in FTC v. Ruberoid Co., 343 U.S. 470, 483-84 (1952).

39 In his dissenting opinion in FTC v. Ruberoid Co., 343 U.S. 470, 480 (1952), Mr. Justice Jackson made the following observation with regard to the Robinson-Patman Act:"This Act exemplifies the complexity of the modern lawmaking task and a common technique for regulatory legislation. It is typical of instances where the Congress cannot itself make every 
It is evident, therefore, that under both the FTC Act and the RobinsonPatman Act the Federal Trade Commission is given both the power and the responsibility of filling in the details of legislation the scope and meaning of which are uncertain. 40 The Commission performs this function chiefly through its only coercive means: the institution and adjudication of cases of alleged misconduct and, in proper instances, the issuance of cease and desist orders. The order resulting from the decision of a case of first impression may thus be regarded as having a dual aspect. It first declares that the particular act of the respondent is an "unfair trade practice" or is "discriminatory." This aspect may be described as the legislative function of the order since it operates to fill in the details of Congress' outline legislation. The second aspect of the order is its formulation of a remedy which is appropriate for the offense committed. If the order prohibits only the proven violations or if its terms are specific, then it operates both legislatively and judicially in its entirety; all parts of the order not only provide a remedy for the offense committed but also clarify the meaning of the statute. However, if the order is both broad and vague, its excessive breadth operates only judicially; the legislative element of such an order extends no farther than, the determination that the particular practice committed is illegal. All orders, by definition, perform a judicial function. But the cease and desist order as a legislative device finds its most extensive use in the context of Trade Commission orders. 41 Whereas the responsibility of the NLRB is to determine whether given conduct violates the rule laid down by Congress, ${ }^{42}$ the Federal Trade Commission frequently

choice between possible lines of policy. It must legislan. . o.ieralities and delegate the final detailed choices to some authority with considerable latitude to conform its orders to administrative as well as legislative policies." Id. at 484.

40 This statement does not apply to the Labeling Acts (see note 7 supra) which are specific and limited in scope.

41 It is of course true that a cease and desist order issued in a case of first impression under any statute, whether vague or specific, "legislates" in that it furtherclarifies the meaning of the statutory language. The difference, therefore, is not one of kind but of degree. The general categories of unfair labor practices have been set forth by Congress. Although the precise meaning of the word "discrimination" in section $8(a)(3)$ of the LMRA is not apparent from the statutory language, it is not difficult to detect from the wording of the Act the general types of activities Congress had in mind when it prohibited "discrimination in regard to hire or tenure." This is not true of section 2(c) of the Robinson-Patman Act, for example. Until the recent case of FTC v. Henry Broch \& Co., 363 U.S. 166 (1960), it was not generally thought that this section prohibited the acceptance of a reduced brokerage commission in return for a seller's agreeing to accept a lower price.

42 This is not to imply that an NLRB order may never operate legislatively. Most of the categories of unfair labor practices have been defined in quite specific terms, leaving little to be filled in by the Board, but section $8(a)(5)$, while declaring that the refusal to bargain collectively is an unfair practice, leaves the determination of the appropriate bargaining unit to the NLRB. Accordingly, orders issued pursuant to decisions involving the question of the appropriate bargaining unit perform a legislative function, and judicial review of these orders is limited. See NLRB v. Packard Motor Car Co., 330 U.S. 485 (1947); Pittsburgh Plate Glass Co. v. NLRB, 313 U.S. 146 (1941); Texas Pipe Line Co. v. NLRB, 296 F.2d 208 (5th Cir. 1961). 
must first determine what the rule is to be. 43 With the exception of one dissenting opinion in the Supreme Court, ${ }^{44}$ this distinction between the legislative and judicial functions of an order has not been drawn in the cases. Its use in this comment as an analytical tool serves two independent purposes. First, and more important, it is submitted as the basis for a workable theory to govern the determination of the proper scope of orders. Second, it is offered as a possible explanation for the different approach of the courts to the problems of the FTC and NLRB orders.

II.

Against this background, the case law development of the doctrine of judicial reliance on FTC discretion may be considered as it relates to the scope of cease and desist orders. Special attention will be given to the influence which the legislative element of Trade Commission orders has had upon the resolution of the problem of breadth.

The reasonable relation test for Trade Commission orders was first articulated in Jacob Siegel Co. v. FTC.45 The Siegel Company, a manufacturer of overcoats and topcoats, marketed its products under the tradename "Alpacuna." The Commission found the use of this name deceptive and misleading in that it induced the erroneous belief that the coats contained vicuna, 46 and the cease and desist order accordingly prohibited further use of the name. ${ }^{47}$ The Supreme Court upheld the FTC's determination that the continued use of "Alpacuna" as a brand name was against the public interest, but it sent the case back to the Commission to consider whether some measure short of complete excision would not be an adequate remedy. 48

Mr: Justice Douglas' opinion stresses the "wide discretion" of the Commission and suggests that this discretion is entitled to equal weight whether it is exercised in drafting the cease and desist order or in determining the substantive issue of whether an unfair trade practice was committed.49 The Court's holding, however, suggests that there is a difference. The FTC had actually considered two separate questions: (1) Is the continued use of the name "Alpacuna" against the public interest? (2) If so, what remedy is appropriate under the circumstances? The first question involved a policy decision; the question of what is in the public interest is the type of problem frequently handled by legislative bodies. The Court gave unqualified approval to the

43 In cases of first impression this will always be true of orders issued under the FTC Act. It may or may not be true of Robinson-Patman orders, depending on whether the violation charged was clearly prohibited by the statute. For cases in which there was no such clear prohibition and the order consequently performed a legislative function, see FTC $v$. Henry Broch \& Co., 368 U.S. 360 (1962) and Swanee Paper Corp. v. FTC, 291 F.2d 833 (2d Cir: 1961).

44 See notes 64-70, infra and accompanying text.

$47 \mathrm{fd}$. at 573.

45327 U.S. 608 (1946).

48327 U.S. at 614.

46 Jacob Siegel Co., 36 F.T.C. 563, 572 (1943).

49 Id. at 611-13. 
Commission's disposition of this issue but sent the second back for further consideration.

FTC v. Cement Institute, 50 decided two years after Siegel, involved a proceeding against an unincorporated association of seventy-four corporations engaged in the manufacture, sale, and distribution of cement. The first count of the Commission's complaint charged that the multiple basing point delivered price system used by the association constituted an unfair method of competition in violation of section 5 of the Federal Trade Commission Act.51 The second count charged further that the system resulted in price discriminations, thereby violating section 2 of the Robinson-Patman Act.52 Finding the respondent guilty on both counts, the FTC issued a cease and desist order designed generally to prohibit the use of any pricing system which "so eliminates competition that respondents' prices are always identical at any given point in the United States." 53 The order did not provide general prohibitions only, however; its second paragraph expressly prohibited sixteen different practices which might be employed in reaching the proscribed objective. 54

The Supreme Court affirmed the agency's holding that the Institute's pricing system was illegal under both the FTC Act and the Robinson-Patman Act. As to the former, the Court sustained:

the Commission's holding that concerted maintenance of the basing point delivered price system is an unfair method of competition prohibited by the Fair Trade Commission Act. In so doing, we give great weight to the Commission's conclusion, as this Court has done in other cases.... We are persuaded that the Commission's long and close examination of the questions it here decided has provided it with precisely the experience that fits it for performance of its statutory duty. The kind of specialized knowledge Congress wanted its agency to have was an expertness that would fit it to stop at the threshold every unfair trade practice-that kind of practice which, if left alone, "destroys competition and establishes monopoly...."ss

The opinion later employs substantially the same rationale in overruling the respondent's objections to the breadth of the order:

[W] also have in mind that the Commission has a wide discretion generally in the choice of remedies to cope with trade problems entrusted to it by the Commission Act. Jacob Siegel Co. v. Federal Trade Comm'n....

There is special reason, however, why courts should not lightly modify the Commission's orders made in efforts to safeguard a competitive econo-

so 333 U.S. 683 (1948).

51 Cement Institute, 37 F.T.C. 87, 97 (1948).

52 Id. at 117.

53333 U.S. at 689. See paragraphs one, three, and four of the order. 37 F.T.C. at $260-61$.

5437 F.T.C. at 260.

55333 U.S. at 720. 
my. Congress when it passed the Trade Commission Act felt that courts needed the assistance of men trained to combat monopolistic practices in the framing of judicial decrees in antitrust litigation. Congress envisioned a commission trained in this type of work by experience in carrying out the functions imposed upon it....56

The legislative element of the FTC's action in Cement Institute, unlike that in Siegel, extended beyond its holding as to the particular practice charged. The case demonstrates that a cease and desist order may be broad without being vague. The enumeration of sixteen specific prohibitions served notice to the cement industry that these practices would no longer be tolerated; in this regard, the remedy itself operated legislatively. The order not only prescribed a penalty for the Institute's violations but also amplified the meaning of "unfair trade practices" and "discriminatory pricing." The order was broad, but its breadth served a legislative as well as a judicial purpose, and the Court, finding no abuse of discretion, deferred to the judgment of the Commission.

Should the choice of remedy be accorded equal deference when the remedy's sole function is a judicial one?

The Supreme Court gave an affirmative answer to this question in FTC $v$. Ruberoid Co.57 The FTC found Ruberoid, one of the nation's largest manufacturers of asphalt and asbestos roofing materials, guilty of price discrimination among its roofing customers in violation of section 2(a) of the RobinsonPatman Act. The Commission's order paraphrased section 2(a) by forbidding the company to discriminate in price: "By selling such products of like grade and quality to any purchaser at prices lower than those granted other purchasers who in fact compete with the favored purchaser in the resale or distribution of such products." 58

The company objected to the order's prohibition of price differentials to any customer, since the findings revealed only differentials of 5 per cent or more to certain types of purchasers.59 Relying on Siegel and Cement Institute for the proposition that "Congress expected the Commission to exercise a special competence in formulating remedies," 60 the Court refused to narrow the scope of the order, stating that:

56 Id. at 726.

57343 U.S. 470 (1952).

58 The Ruberoid Co., 46 F.T.C. 379, 387 (1950).

s9 The discounts complained of in Ruberoid were functional discounts, i.e., they were based on the buyer's status as a wholesaler, retailer, or applicator. Such discounts are often allowed, since the various categories of purchasers are not in competititon with each other. EDWARDS, 267. In the present case, however, some purchasers were in business both as roofing contractors and as wholesalers or retailers. Ruberoid did not require them to segregate for discount purposes materials purchased for different operations.

60343 U.S. at 473. 
The Commission is not limited to prohibiting the illegal practice in the precise form in which it is found to have existed in the past. If the Commission is to attain the objectives Congress envisioned, it cannot be required to confine its road block to the narrow lane the transgressor has traveled; it must be allowed effectively to close all roads to the prohibited goal, so that its order may not be by-passed with impunity. Moreover, " $[t]$ he Commission has wide discretion in its choice of a remedy deemed adequate to cope with the unlawful practices" disclosed. Jacob Siegel Co. v. Federal Trade Comm'n ....61

These cases illustrate one line of authority which holds that FTC decisions which amplify statutory meaning are entitled to great weight on review.62 Accompanying that principle there has developed the equally firm notion that the scope of an FTC order should be narrowed only if the Commission has abused its discretion. ${ }^{63}$ Thus, in deferring to the discretion of the Commission the Supreme Court has not differentiated between the legislative and judicial elements of the order. Attention will now be directed to the proposition that such a differentiation is needed.

III.

Mr. Justice Jackson's vigorous dissent in Ruberoid argued that the issuance of an order which paraphrases the language of a statute such as the RobinsonPatman Act violates Congress' intent and imposes an improper burden on the respondent. The congressional decision to legislate in generalities, delegating the final detailed choices to the Federal Trade Commission, ${ }^{64}$ he emphasized, meant that until the agency had completed the expression of legislative will by filling in the blank spaces of the statute, there was nothing for the court to enforce, 65 since the responsibility of enacting this "secondary legislation" 66 could not be assumed by the judiciary. It is axiomatic, he observed, "that the work of a Commission in translating an abstract statute into a concrete cease and desist order in large measure escapes judicial review because of its legislative character. ..."67 Furthermore, "since it is difficult for

61 lbid.

62 There is another line of cases, none of which involved the question of the proper scope of orders, holding that "it is for the courts, not the commission, ultimately to determine as a matter of law what [the words, "unfair method of competition'] include." FTC v. Gratz, 253 U.S. 421,427 (1920). See also FTC v. Motion Picture Advertising Service Co., 344 U.S. 392, 404 (1952). In view of the statement by the Senate Committee that it had decided to "leave it to the commission to determine what practices were unfair" (see note 34 supra), it would appear that the better approach is to defer to the Commission's discretion exercised in making these determinations.

63 It has been suggested that this development is at least partially due to the fact that the distinction between the legislative and judicial functions of an order has not been made. See note 67 , infra and accompanying text.

64343 U.S. at 484.

65 Id. at 487.
66 Ibid.

67 Id. at 490. 
a court to determine from the record where quasi-legislative policy making has stopped and quasi-judicial application of policy has begun, the entire process escapes very penetrating scrutiny. "6: But in the instant case there should be no such escape because the Commission had merely "promulgate[d] as its own decision the generalities of its statutory charter. . .." 69 Therefore, Mr. Justice Jackson would have:

Remanded to the Commission with directions to make its order specific and concrete, to specify the types of discount which are forbidden.... The Commission should, in short, in the light of its own policy and the record, translate this Act into a "set of guiding yardsticks," admittedly now lacking. If that cannor be done, there should be no judicial approval for an order to cease and desist from we don't know what. 0

Mr. Justice Jackson's dissent has been widely cited for various purposes,, 1 but its most important message has gone largely unheeded. It is proper that the courts defer to Commission discretion exercised in carrying out a legislative function. The responsibility for clarifying the scope and meaning of the FTC Act and the Robinson-Patman Act was committed by Congress to the Commission, not to the courts.72 Furthermore, the FTC's specialized knowledge of trade practices and their effect on the national economy makes this body particularly well qualified to determine which practices are against the public interest. ${ }^{73}$ It does not follow that this discretion should be accorded equal deference when the only question involved is the measure of punishment which should be imposed upon one who has violated the law. A distinction should be drawn between orders which are broad and those which are both broad and unclear. The broad scope of an order which enumerates specific prohibitions, such as that in Cement Institute, performs a legislative function and should be upset only if there has been an abuse of discretion. But the legislative element of an order which merely paraphrases the statute, as in Ruberoid, extends no further than the proven violations. Expanding the order beyond those violations serves only the judicial function of devising a remedy for the offense committed. This is the type of problem which the courts face every day; in this area the judges are fully as expert as the commissioners. Therefore, if the statutory provision under which a cease and desist order

68 Id. at 491.

69 Id. at 489.

To Id. at 493-94.

71 See, e.g., I DAiTs, ADMIMSTRATIVE LAR: $\$ 1.02$ (1958); Rowe, The Evolution of the Robinson-Patman Act: A Twenty-Year Perspective, 57 CoLt3. L. REv. 1059 (1957).

72 See notes 34 and 62 , supra.

73 "[There are .. . sound reasons why these agencies have been entrusted with a discretionary authority ... [one of these being that] Congress possesses neither the scientific knowledge nor the technical competence to define completely the national policy in many of its more complicated aspects." Cooper, Administrative Justice and the Role of Discretion, 47 YALE L.J. 577,581 (1938). 
issues is as vague as section 5 of the Federal Trade Commission Act or any of the sections of the Robinson-Patman Act, and the prohibitions by the order of practices other than the proven violations serves to clarify the meaning of the statutory language, the order should be entitled to great weight on review. But an order whose excessive breadth does not serve further to clarify the statute should be subject to close scrutiny by the reviewing court regardless of the agency from which it issues. 74

An analysis of cease and desist orders in terms of the functions which they perform suggests that under certain circumstances the courts should be even more willing to modify orders of the FTC than those of the NLRB. An examination of the criteria which determine the permissible scope of NLRB orders reveals that when the broad scope of a Labor Board order serves only a judicial purpose it may not prohibit acts other than those of which the respondent has been found guilty unless there is shown a reasonable probability that he intends to engage in the prohibited acts. ${ }^{75}$ It is submitted that this approach is correct as a matter of practical application and that it follows logically from the statutory requirements for issuing cease and desist orders. All statutes authorizing the use of cease and desist orders provide that no order may issue until there has been a proven violation. 76 Since the theory underlying these decrees is that they are not to punish for past activities but to prevent future misconduct, 77 the requirement that a violation be proven must be explained in terms of the inference which it reasonably supports as to the violator's intended future conduct. There is no reason to abandon this inquiry as to probable intention once the threshhold requirement of a violation has been satisfied. The perfect cease and desist order, one which would completely satisfy the dual demands of administrative fairness and effectiveness, would prohibit precisely those illegal acts which the respondent will in fact commit.

74 This does not mean that under no circumstances should an FTC order be broader than an NLRB order. For example, the reviewing court may properly take account of the physical circumstances surrounding the respondent in given cases. Whereas a merchant may daily engage in hundreds of sales transactions with many different customers, an employer engages in contract negotiations with a single union only once in several years. In comparing the proper breadth of an order founded on the commission of an unfair advertising practice with an order based on a refusal to bargain collectively, the opportunities for future violation should be taken into account.

75 See notes 24 and 25 , supra and accompanying text.

76 See, e.g., 38 Stat. 722 (1914), 15 U.S.C. § 45(b) (1958); 61 Stat. 146 (1947), 29 U.S.C. $\$ 160$ (c) (1958).

77 "The function of the order is not to punish but to declare a rule of conduct for the future which will avoid further violation of the law." Freer, Federal Trade Commission Procedure and Practice, 8 GEO. WAStr. L. REV. 316, 330 (1940). "The object of the proceding is to stop the unfair practice. If the practice hes been surely stopped and by the act of the party offending, the object of the proceeding having been attained, no order is necessary, nor should one be entered. If, however, the action of the wrongdoer does not insure a cessation of the practice in the future, the order to desist is appropriate."' Eugene Dietzgen Co. v. FTC, 142 F.2d 321, 331 (7th Cir. 1941). 
Since the consistent issuance of such orders could be achieved only through superhuman predictive capacities, the best alternative is to come as close to the ideal as possible by enjoining those activities of which it can be said, as a matter of reasonable inference from past conduct, that the respondent probably intends to commit.

It therefore appears that the critical factor in determining the permissible breadth of the judicial element of a cease and desist order is the implied intention of the wrongdoer. It follows that when the question is the scope of the judicial element of an order which also operates legislatively, there may be greater reason for narrowing the decree than when it serves only a judicial purpose. An intention to violate can hardly be inferred from the perpetration of an act which prior to the proceeding before the Commission was not known to be illegal. Furthermore, the vagueness of the congressional legislation, the very circumstance which makes it necessary that the Commission perform the task of completing "skeleton legislation," 78 should also suggest that orders issued under that legislation be specific. An order which paraphrases a statute whose terms are relatively specific may be objectionable because it prohibits too much. An order which paraphrases a vague statute is subject to the additional objection that it is impossible to ascertain what it prohibits.79

Even though as a practical matter intensive review of the judicial element of FTC orders might be called for, there may be a countervailing argument that this is opposed to the intent of Congress. It is often asserted that "Congress expected the Commission to exercise a special competence in formulating remedies," 80 from which it may be argued that the terms of the order should be entitled to great weight regardless of the type of function performed. A study of the legislative history cited for this proposition certainly does not compel the conclusion that it is correct.81 But even assuming that the statement is true, the argument which follows from it is self-defeating when applied to an order drafted substantially in the terms of the statute. It requires no special competence merely to repeat what Congress has already said. If Congress intended that all orders drafted on the basis of FTC "expertise" should be entitled to great weight, no violence is done to this intent by restricting the scope of an order which is not in fact the product of expert judgment.

But, why, it has been asked, should any respondent object to the issuance of a cease and desist order, no matter how broad its terms? The order itself imposes no punishment; it simply instructs its receipient to obey the law, 82

78 FTC v. Ruberoid Co., 343 U.S. 470, 485 n.7 (1952) (dissenting opinion).

79 "Admitting that the statute is 'vague and general in its wording,' it does not follow that a cease and desist order implementing it should be." Id. at 481.

80 FTC v. Ruberoid Co., 343 U.S. 470, 473 (1952).

81 See S. Rep. No. 597, 63d Cong. 2d Sess. 13 (1914).

82 In answer to the objection that an order issued to Colgate-Palmolive Co. prohibiting the use of "spurious mock-ups or demonstrations for any product" was too broad, Commissioner Dixon is reported to have said, "all we are ordering them to do is to obey the Law." Time, Feb. 2, 1962, p. 61. 
and society should have the right to expect him to do this whether or not he has received an order from the Federal Trade Commission. Is it not fair to say that the only possible motive for a respondent's objection to the breadth of a cease and desist order must be that he contemplates engaging in the conduct which it forbids? Although some courts have found this argument persuasive ${ }^{83}$ it oversimplifies the problem. A respondent's objection to the breadth of an FTC order frequently derives from more significant interests than mere reluctance to be deprived of the one unpunishable violation which the cease and desist order mechanism allows.

The recent case of FTC v. Henry Broch \& Co.84 illustrates these interests. The case also emphasizes the potentially unfortunate consequences of reliance on the wide discretion of the Commission without distinguishing between its exercise in a judicial context and its exercise in a legislative context. Broch \& Co., a Chicago brokerage partnership acting as a seller's agent for some twenty-five principals, agreed to accept a three per cent commission on a particular sale of apple concentrate, instead of the usual commission of five per cent, from one of these principals, Canada Foods. In return, Canada Foods lowered its price from the established $\$ 1.39$ per gallon to $\$ 1.25$ per gallon, the highest price which the buyer, J. M. Smucker Co., was willing to pay. The Commission determined that these activities fell within the ambit of section 2(c) of the Robinson-Patman Act and ordered Broch to cease and desist from (1) repeating the particular violation committed, in connection with sales for Canada Foods or "any other seller" to J. M. Smucker or "any other buyer," and (2) in effect, granting anything of value to Smucker or any other buyer in such manner as to violate section 2(c) of the Robinson-Patman Act.85

In a 6-3 decision, the Supreme Court upheld both sections of the order, thus reversing the action of the court of appeals which had struck out all reference to "any other" buyer or seller.86 Citing Siegel and Cement Institute, the Court emphasized the wide discretion enjoyed by the Commission in framing its orders and asserted that in the instant case the Court could "not say that the Commission exceeded its discretion." 87 Broch contended that despite the lower court's deletion of the references to all other individuals, the second

83 See. e.g., Edward P. Paul \& Co. v. FTC, 169 F.2d 294, 296 (D.C. Cir. 1948).

84368 U.S. 360 (1962). In a former decision, FTC v. Henry Broch \& Co., 363 U.S. 166 (1960), the Court had considered and affirmed the Commission's decision that Broch's conduct was in violation of section 2(c) of the Robinson-Patman Act. See Comment, $28 \mathrm{U}$. CHI. L. Rev. 505 (1961).

85 The second part of the order prohibited: "In any other manner paying, granting or allowing, directly or indirectly, to the J. M. Smucker Company, or to any other buyer, or to anyone acting for or in behalf of or who is subject to the direct or indirect control of such buyer, anything of value as a commission, brokerage or other compensation or any allowance or discount in lieu thereof upon, or in connection with, any sale of food or food products to such buyer for its own account." Henry Broch \& Co., 54 F.T.C. 673, 694 (1957).

86 Henry Broch \& Co. v. FTC, 285 F.2d 764 (7th Cir. 1960).

87368 U.S. at 364. 
paragraph was still "so bropad as to jeopardize the conduct of his entire business, in that it unqualifiedly prohibited reductions of commissions coupled with lower prices ...." 88 Rejecting this argument, the Court reasoned that the effect of the blanket order on the respondent's business was minimized by the fact that its provisions would be enforced under pre- 1959 procedure. 89 This reasoning is not without some force. The chief objection to an order such as that in Broch is not that it is too broad, but that it does not sufficiently inform the respondent as to the acts which he is forbidden to commit. Since the pre-1959 procedure allowed the respondent another violation without punishment, 90 it was possible that the objectionable vagueness would be eliminated prior to the violation for which contempt proceedings are instituted. The weakness of the position is its assumption that the order extends to no more than one practice whose legality is uncertain. Under the Robinson-Patman Act, this is a very questionable assumption. 91

Mr. Justice Whittaker, with whom Justices Frankfurter and Harlan joined in dissent, would have affirmed the judgment of the court of appeals. The dissenters contended that in shaping its order the Commission should distinguish between "a specific closely confined illegality" and "a widespread practice." 92 In view of the exclusively judicial function performed by the order, the argument that its broad language should at most be allowed to extend no farther than the parties involved becomes quite persuasive. The order made no attempt to legislate; its terms simply paraphrased the prohibitions of section 2(c). Agency discretion should therefore not be a factor; the sole question was whether as a judicial measure this order was the appropriate remedy. The Commission charged and proved only one allowance in lieu of brokerage accepted from one seller on a single sale to one buyer. At the time this transaction occurred, it was not known that the acceptance of such an allowance was illegal.93 Although support may be found in other contexts for the prin-

88 Ibid. See Brief for Respondent, pp. 13-14.

89368 U.S. at 365. The committee which recommended the passage of the new procedure also suggested that "the commissions and boards affected by the bill will make a continuous effort to issue orders that are as definitive as possible." 2 U.S. Cong. \& Admin. News 1807 (i959). It should be pointed out that during the twenty-one years in which the FTC enforced the Robinson-Patman Act under one procedure and the FTC Act under another (see note 13, supra), this is the first suggestion made either by Congress or the courts that the difference in procedure should affect the breadth of orders. Such a suggestion had been made, however, in JafFe, AdMinistratitve LAW CASES AND MATERIALS 480-81 (1954).

90 See note 13, supra.

91 The Broch case itself, on the first appeal, raised new uncertainties as to the scope of section 2(c). See Comment, 28 U. CHI. L. REv. 505, 515-16, for two brokerage practices whose legality is placed in doubt by the first Broch case.

92368 U.S. at 369. This emphasis on the extent of past violations resembles the approach generally used in determining the proper breadth of NLRB orders. See note 25 , supra and accompanying text.

93 See Comment, 28 U. Chr. L. Rev. 505 (1961). 
ciple that the reasonably implied intention of the respondent should be the critical determinant of the proper scope of the judicial element of cease and desist orders, that principle was not followed in Broch. For the commission of an isolated act which he had reason to believe was permitted by the statute the respondent was burdened with an order enjoining him from violating section 2(c) in any manner and with any person. It would be difficult to imagine a more extreme example of judicial reliance on agency discretion.

The potential unfairness of an order like that in the Broch case is compounded by the FTC's practice of selective enforcement. 94 In performing its responsibility of clarifying the Robinson-Patman Act, the Commission does not attempt to investigate and issue orders to all firms engaging in a particular practice within an industry. Primary emphasis is placed on the legislative element of the order in that a decree to one firm serves notice to all that the practice is illegal.95 From the standpoint of the Commission, this selective procedure is highly advantageous; otherwise, the policing of pricing practices throughout the nation by a single agency would be virtually impossible. 96 For the individual selected as the exemplary case, however, the method may be harsh. One firm must bear the inconvenience and expense of a hearing, and possibly an appeal, in order to clarify the law for the entire industry. If it is determined that the statute has been violated, the cease and desist order applies only to the individual respondent. If selective enforcement succeeds as intended his competitors will also conform to the terms of the decree, but there is no legal machinery to compel them to do so. Similar orders may be issued to nonconformers, but there will always be a time lag during which the respondent will be at a substantial disadvantage if his competitors do not choose to observe the order. ${ }^{97}$ Without attempting to assess the relative merits of selective enforcement by the FTC,98 it is sufficient for present purposes to observe that the inequities of the system should not be compounded by imposing upon the respondent the additional burden of an order which extends far beyond the practice at issue.

\section{IV.}

Probably more important than the propriety of the holding in Broch is a question which was not before the Court but was alluded to in a dictum: Will Robinson-Patman orders issued under the new enforcement procedure be

94 This practice is discussed and criticized in Note, 13 RutGers L. Rev. 315 (1958).

95 In the twenty-one year period between the effective date of the Robinson-Patman Act and December 31, 1957, only 311 cease and desist orders, less than fifteen per year, were issued under the statute. EDWARDs 66.

96 See Note, 13 Rutgers L. Rev. 315 n.3 (1958).

97 The Supreme Court has held that a court of appeals may not suspend the operation of a cease and desist order pending the entry of similar orders against respondent's competitors. Moog Indus., Inc. v. FTC, 355 U.S. 411 (1958) (per curiam).

98 For a suggested reform, see Note, 13 RutGers L. Rev. 315 n. 3 (1958). 
reviewed more critically? This possibility is suggested by the closing paragraph of the majority opinion:

We do not-wish to be understood, however, as holding that the generalized language of paragraph (2) would necessarily withstand scrutiny under the 1959 amendments. The severity of possible penalties prescribed by the amendments for violations of orders which have become final underlines the necessity for fashioning orders which are, at the outset, sufficiently clear and precise to avoid raising serious questions as to their meaning and application. 99

There is much to recommend the soundness of this dictum. It has been pointed out above that a broad order issued under the new procedure is more likely to result in unfairness to the respondent. 100 Also, since the Commission has been given a more effective enforcement tool there would seem to be less need for broad orders.101 However, since 1938 the Commission has employed the identical procedure under the FTC Act which it is now authorized to use under the Robinson-Patman Act; no court has ever suggested that the differences in procedure under these two statutes should alter the principle that the discretion of the Commission may be upset only if clearly abused.102 Nevertheless, if respondents' counsel are successful in their attempts to focus attention upon the words "clear and precise," 103 the Broch case may mark not the culmination but the turning point in the development of the doctrine of FTC discretionary power.

This possibility is strengthened by a series of recent cases in the Second Circuit.104 Two of these cases arose out of the same set of facts, although there was a seven-month interval between the decisions. The Swanee Paper Corporation purchased advertising space on a large outdoor sign from the Grand Union Company, a buyer of Swanee's paper products. The Commission ruled, and the court of appeals agreed, that these dealings constituted a violation by Swanee of section 2(d) of the Robinson-Patman Act, since the payments were in consideration of services rendered by Grand Union and conferred a benefit not available to other customers of Swanee on a proportion-

99368 U.S. at 367-68.

100 See note 90, supra and accompanying text.

101 In support of its argument that the order in Ruberoid was not excessively broad the Commission stressed the ineffectiveness of a method which permits two free violations before punishment is imposed. Brief for FTC, pp. 19-20; FTC v. Ruberoid Co., 343 U.S. 470 (1952).

102 Siegel arose under the FTC Act, Ruberoid. under the Robinson-Patman Act, and Cement Institute under both.

103 For a recent example, of such an attempt, see Supplemental Memorandum for Respondent, pp. 4-6, Max Factor \& Co., No. 7717 FTC (Feb. 21, 1962).

104 American News Co. v. FTC, 300 F.2d 104 (2d Cir. 1962); Grand Union Co. v. FTC, 300 F.2d 92 (2d Cir. 1962); Swanee Paper Corp. v. FTC, 291 F.2d 833 (2d Cir. 1961). Swanee was denied certiorari in 368 U.S. 987 (1962). 
ally equal basis. 105 Orders paraphrasing section 2(d) were issued to Swanee under the Robinson-Patman Act and to Grand Union under the FTC Act.106 On authority of NLRB v. Express Publishing Co., 107 the court in the Swanee case held that a single violation in an uncertain area of the law would not support such a broad prohibition; the scope of the order was therefore confined to the particular violation found. 108

By the time the order to Grand Union came up for review, the Supreme Court had rendered its decision in Broch. ${ }^{109}$ Although the opinion mentioned the wide discretion of the Commission, the court examined the order as critically as it would a decree of the NLRB and, as in Swanee, restricted its scope to the proven violation. ${ }^{110}$ The almost perfect similarity between Grand Union and Broch was disposed of by Judge Clark in a footnote statement: "We find nothing in the recent opinion in FTC v. Henry Broch \& Co. ... which is inconsistent with our finding that the Commissions' orders are too broad. As that case suggests, in situations where agency orders are subject to automatic enforcement in civil suits brought by the Attorney General, these orders must be clear and specific."111 This application of the Broch dictum could prove to be the entering wedge for more intensive rekiew of the judicial element of FTC orders. The rationale of the court in Grand Union was that since the Commission had proven only a single violation, and the application of section 5 to respondent's conduct was "admittedly novel,"112 there was "nothing in the record to suggest that Grand Union intends to resume this or any related activity."113 In future cases arising under the new enforcement procedure the

105 Id. at 835-36.

106 Section 2(d) does not cover the acceptance of advertising payments by buyers. However, the Commission held that Grand Union's conduct was an unfair trade practice, and consequently could be prohibited under section 5 of the Federal Trade Commission Act. In upholding this legislative determination, Judge Clark stated: "Congress established the Federal Trade Commission as an expert body to apply the imprecise standards of $\S 5$, and 'its expert opinion is entitled to great weight in the reviewing courts.' Jacob Siegel $\mathbf{C}$. . v. FTC...." Grand Union Co. v. FTC, 300 F.2d 92, 99 (2d Cir. 1962). A similar holding and rationale prevailed in American News Co. v. FTC, 300 F.2d 104 (2d Cir. 1962). These two cases emphasize the unlimited scope of section 5.

107312 U.S. 426 (1941). Express Publishing is the leading authority for the proposition that an excessively broad order may be modified. It is therefore interesting to note that the party adversely affected by the order in that case did not object to its wide scope. See Brief for Respondent. The winning argument in the case was advanced by the Singer Sewing Machine Co., which filed an amicus curiae brief devoted exclusively to the question of breadth. Eighteen days after Express Publishing was decided, it was followed in Singer Mfg. Co. v. NLRB, 119 F.2d 131 (7th Cir. 1941).

108 Swanee Paper Corp. v. FTC, 291 F.2d 833, 838 (2d Cir. 1961).

109 Swanee was decided on June 22, 1961, Broch on January 15, 1962, and Grand Union and American News on Feb. 7, 1962.

110 Grand Union Co. v. FTC, 300 F.2d 92, 100-01 (2d Cir. 1962).

$111 \mathrm{Yd}$. at $101 \mathrm{n} .21$.

$112 \mathrm{Id}$. at 100.

113 Ibid. (Emphasis added.) 
two determinative factors in Swanee and Grand Union-a single violation in an uncertain area of the law-may not appear in combination. Under such circumstances advocates of broad orders may contend that Commission discretion should be controlling. It is doubtful that such an argument will prevail. There is no indication in either Swanee or Grand Union that the search for implied intent should be limited to cases in which these two factors are present.114

\section{V.}

Both the administrative agency and the respondent have a vital interest in the scope of activities which a cease and desist order prohibits: an order which is too narrow may allow the wrongdoer to continue the pursuit of his illegal purpose by a slight alteration in method; an excessively broad order may place the respondent at an unfair competitive disadvantage.

The traditional reasonable relation test for determining the permissible breadth of cease and desist orders is being applied more strictly to orders of the NLRB than to those of the FTC. Reviewing courts consistently narrow the scope of Labor Board decrees to the proven violations unless the findings support a reasonable inference that the respondent intends to engage in other illegal conduct. The Federal.Trade Commission, on the other hand, enjoys wide discretion in framing its remedies, a discretion that is controlling unless. clearly abused.

Under proper circumstances there is a defensible rationale for this double standard of review. In addition to the judicial function performed by all cease and desist orders, Federal Trade Commission orders issued under the FTC Act and the Robinson-Patman Act may also perform a legislative function in defining the acts to be regarded as unfair trade and discriminatory pricing practices. Congress has delegated the performance of this function to the FTC, whose specialized knowledge of trade practices qualifies it to discharge this responsibility. Therefore, the legislative element of an FTC cease and desist order should be upset only when the Commission has abused its discretion. If the terms of the decree are broad but specific, possible inequities accruing to the individual respondent from such an order may be outweighed by the need to give effect to congressional intent.

The wide scope of a cease and desist order which paraphrases the language of the statute serves no purpose other than the formulation of an appropriate remedy. Judicial deference to the discretion of the Commission exercised in performing this judicial function is not required by congressional directive and may result in unfortunate consequences to the respondent. In the absence

114 Commissioner Kern has characterized the Broch opinion as a "warning signal against the issuance of broad orders couched in the language of the statute violated unless a clear predicate is laid in the record justifying the necessity for such an order." Address by Commissioner William C. Kern, Ohio Valley Business Conference of Xavier University, Feb. 3, 1962. 
of findings from which it can reasonably be inferred that the respondent intends to engage in other illegal acts, the scope of an order which operates only judicially should be restricted to proven past misconduct, regardless of the agency from which the order issues. In general, the cases have not distinguished between the judicial and legislative elements of FTC orders. The consistent approach of reviewing courts has been to defer to the discretion of the Commission without regard to whether this discretion was exercised in a judicial or a legislative context. However, recent cases in the Second Circuit interpreting the dictum in FTC v. Henry Broch \& Co. may be pointing toward an approach generally consistent with the legislative-judicial function analysis. 115

115 Swanee, Grand Union, and American News all involved orders which paraphrased section 2(d) of the Robinson-Patman Act. There has been no comparable development toward closer scrutiny of orders implementing the FTC Act or the Labeling Acts. See, e.g., Exposition Press, Inc. v. FTC, 295 F.2d 869 (2d Cir. 1961); Hoving Corp. v. FTC, 290 F.2d 803 (2d Cir. 1961).

In general, reliance on agency discretion in reviewing orders under the FTC Act is consistent with the legislative-judicial function analysis. Because of the scheme on which the Act is constructed, any order in a novel case performs a legislative function; there are no statutory categories which the order can paraphrase, and no decree has yet prohibited all unfair trade practices.

As to orders issued under the Labeling Acts, the thesis of this comment would require a stricter application of the reasonable relation test. The categories of unfair practices are limited and specific; orders pursuant to their authority are primarily for the purpose of enforcement, not interpretation. 